\title{
Where are the turtles when they are not? Underwater refuges used by Hydromedusa tectifera COPE, 1869 in a suburban stream
}

\author{
María B. Semeñiuk ${ }^{1,2}$ (D) María J. Cassano ${ }^{1,3} \cdot$ Rocío M. Sánchez ${ }^{1,3}$. Ezequiel Palumbo ${ }^{3,4} \cdot$ Leandro Alcalde $^{1,3}$ \\ Published online: 14 May 2020 \\ (C) Springer Science+Business Media, LLC, part of Springer Nature 2020
}

\begin{abstract}
Habitat requirements of Hydromedusa tectifera from an urban impacted stream from the Buenos Aires province, the Rodriguez stream, are here studied. We describe the type of underwater refuges, how they are used in different stream sections, stream margins, year season, size class and sex of the individuals, and analyze patterns of recurrence and aggregative use of refuges. Fieldwork was carried out from March 2017 to January 2018. Turtles were caught manually recording the following variables: site, transect and margin, sex, straight carapace length, and weight. Substrate types are differently used according to stream section, stream margin, year season and size class of individuals, but no difference was found between sexes. In the whole stream, most used refuges were the hollows on the margins (55.05\%), followed by marginal aquatic vegetation (19.27\%). Turtles of all class sizes and both sexes refuge into hollows on the stream margins. Despite different microhabitats provide refuge to turtles during all year seasons, hollows are the most important refuge during extreme cold and extreme hot seasons. In addition, turtle recaptures evidence a recurrence and aggregative pattern in the use of refuges. This information provides insight into the key aspects of the microhabitat requirements of the species and will be certainly useful in mitigating and preventing negative effects of the current stream management policies. It is worth highlighting the need to keep the stream margins unaltered to favor the presence of turtles in urban environments.
\end{abstract}

Keywords Habitat use $\cdot$ Hydromedusa tectifera $\cdot$ Snake-necked turtle $\cdot$ Substrate type $\cdot$ Suburban stream $\cdot$ Underwater refuges

\section{Introduction}

Urban expansion has caused drastic changes in natural landscapes across the world. The undesirable effects of urbanization involve habitat fragmentation and degradation, pollution, introduction of exotic species and road mortality. The combination of all these factors leads to declining populations and local extinction of certain species. Mitchell et al. (2008) summarized most of the work in urban amphibians and reptiles, and recently, French et al. (2018) published a review of reptilian responses to specific urban features.

María B. Semeñiuk

mbelen_semeniuk@fcnym.unlp.edu.ar

1 Sección Herpetología, Instituto de Limnología Dr. R. A. Ringuelet, Boulevard 120 y 62, CP 1900 La Plata, Buenos Aires, Argentina

2 Universidad Nacional de La Plata, La Plata, Buenos Aires, Argentina

3 Concejo Nacional de Investigaciones Científicas y Técnicas, Buenos Aires, Argentina

4 Centro de Estudios Parasitológicos y de Vectores, Boulevard 120 y 62, CP 1900 La Plata, Buenos Aires, Argentina
The impact of urbanization on several turtle species has been reported by many authors (e.g., Ner and Burke 2008; Plummer and Mills 2008; De Lathouder et al. 2009; Rees et al. 2009; Eskew et al. 2010a, b; Roe et al. 2011; Sterrett et al. 2011; Hill and Vodopich 2013; Stokeld et al. 2014; Elston et al. 2016; Ferronato et al. 2016, 2017; Santoro 2017; Bowne et al. 2018; Dupuis-Desormeaux et al. 2018; Semeñiuk et al. 2019; Vanek and Glowacki 2019). Many of them have demonstrated that turtle populations have a neutral, and even positive, response to urban impacts according the degree of habitat modification (Plummer and Mills 2008; Eskew et al. 2010a, b; Roe et al. 2011; Stokeld et al. 2014; Ferronato et al. 2017; Dupuis-Desormeaux et al. 2018; Semeñiuk et al. 2019). However, Eskew et al. (2010b) emphasize that there may be a lag period between the beginning of human disturbance and its effect on populations.

Knowledge of the spatial ecology and habitat requirements is essential to understand how urbanization impacts on the species, in order to effectively manage urban habitats (Ryan et al. 2014). However, for most turtles this is poorly known. Freshwater turtles are particularly vulnerable to habitat fragmentation, as they not only depend on the aquatic environment, but also need the terrestrial environment for nesting, 
basking, dispersal and hibernation (Marchand and Litvaitis 2004; Ryan et al. 2008; Wieten et al. 2012; Hill and Vodopich 2013; Ryan et al. 2014; Hamer et al. 2018).

The South American snake-necked turtle Hydromedusa tectifera is widely distributed through Uruguay, southeastern Brazil, eastern Paraguay, and northeastern and central Argentina (Sánchez et al. 2019). In a recent paper, Semeñiuk et al. (2019), demonstrated that key population parameters of H. tectifera are not impacted by the moderate suburban settlement (La Plata city, eastern Argentina). In this work some aspects of habitat use in that population of the Rodriguez stream are further studied by (1) describing the type of underwater refuges use by turtles, (2) analyzing how these refuges are used in different stream sections, stream margins, year season, size class and sex of the individuals, and (3) the evaluation of recurrence patterns and aggregative use of refuges. Our interest was not to test any particular hypothesis, but to generate baseline information that could be useful to prevent the effects of urbanization on the species and, if necessary, to mitigate impacts by creating adequate habitats in streams already disturbed.

\section{Materials and methods}

\section{Study area}

Field work was made in a tributary of the Río de la Plata River, the Rodriguez stream, in the suburbs of La Plata city (Buenos Aires province, Argentina). We chose three stream sections with different degree of urbanization along the margins, in 10 ha that enclose each stream section: (S1) upstream, rural zone without housing on the margins; (S2) midsection, sparsely populated (urbanization density intermediate between $\mathrm{S} 1$ and S3: 3 houses/ha); and (S3) midsection downstream from S2, higher urbanization density with 5 houses/ha. Sites 1 and 2 are separated by $4.5 \mathrm{~km}$ of stream course (not in a straight line) and Sites 2 and 3 by $4.2 \mathrm{~km}$. These sections are travesed by different street types and traffic intensities in the 10 ha that surround each site (Table 1). In sum, S1 lacks houses and is traversed by a single narrow foot path (not enabled for vehicles); $\mathrm{S} 2$ is moderately housed and traversed by a single paved

Table 1 Characteristics of the urbanization in the 10 ha that surround each stream section

\begin{tabular}{lllll}
\hline Site & $\begin{array}{l}\text { Degree of } \\
\text { urbanization } \\
\text { (houses/ha) }\end{array}$ & $\begin{array}{l}\text { Paved } \\
\text { street } \\
(\mathrm{m})\end{array}$ & $\begin{array}{l}\text { Unpaved } \\
\text { street }(\mathrm{m})\end{array}$ & $\begin{array}{l}\text { Motor vehicles/ } \\
\text { min }\end{array}$ \\
\hline S1 & 0 & 0 & 0 & 0 \\
S2 & 3 & 320 & 450 & 13 \\
S3 & 5 & 700 & 0 & 22 \\
\hline
\end{tabular}

street (very busy) and a net of low-traffic unpaved streets; and S3 highly housed and crossed by paved streets. Motor vehicle traffic also increases from $\mathrm{S} 1$ to $\mathrm{S} 3$, measured during $5 \mathrm{~min}$ in periods of intense traffic between 800 and $900 \mathrm{~h}$ (Table 1 quantifies these urban characteristics).

Stream width is highest in S3 (range: 7.9-9.9 m, mean = $8.91 \pm 0.55 \mathrm{~m}$ ), followed by S2 (range: $4.2-7.3 \mathrm{~m}$, mean $=$ $6.27 \pm 0.93 \mathrm{~m}$ ) and $\mathrm{S} 1$ (range: $2.8-6 \mathrm{~m}$, mean $=3.97 \pm$ $0.92 \mathrm{~m}$ ). Mean water depth is highest in $\mathrm{S} 2$ where it ranges from 18 to $43.67 \mathrm{~cm}$ (mean $=28.76 \pm 6.74 \mathrm{~cm})$, while in $\mathrm{S} 3$ it ranges from 6.67 to $23.67 \mathrm{~cm}$ (mean $=14.78 \pm 5.15 \mathrm{~cm}$ ) and in $\mathrm{S} 1$ it ranges from 8 to $22.17 \mathrm{~cm}$ (mean $=12.47 \pm 4.19 \mathrm{~cm}$, Table 2$)$.

\section{Sampling methods}

Between March 2017 and January 2018 the stream was visited three times in autumn, one in winter, two in spring, and one in summer, totalizing seven work days (between 10:00 $\mathrm{h}$ and 16:00 h). Turtles were actively searched (visual and tactile encounters, hand collection) on both stream margins following five $30-\mathrm{m}$ long transects by stream section, with $15 \mathrm{~m}$ separation between consecutive transects. Both stream margins of each transect were inspected simultaneously. The substrate types (Fig. 1) used by turtles as underwater refuges were grouped into four categories in order to facilitate analysis: (1) marginal aquatic vegetation; (2) hollows on the stream margins; (3) nude stream bottom, and (4) other substrate types such as garbage accumulations, logs and floating dams composed by rests of aquatic and terrestrial vegetation. The area $\left(\mathrm{m}^{2}\right)$ occupied by each substrate type in each of the three stream sections was estimated only once during winter (Table 3).

Each caught turtle was in-situ recorded for the following variables: (1) site (1-3), number of transect (1-5), and margin of stream (North-South); (2) capture location (position on transect); (3) substrate type (see above); (4) sex; (5) weight; and (6) straight carapace length (SCL: straight distance between anterior margin of nuchal scute and posterior margin of supracaudals). Turtles were sexed according to sexually dimorphic characteristics (Cabrera 1998) and, in the case of smaller specimens with no clear plastron concavity, by the presence of penis within the cloaca following Rodrigues et al. (2014). Finally, turtles were individually marked according to Cagle (1939) and released at the location of capture.

\section{Data analysis}

Multiple Correspondence Analysis was applied to elucidate the relationship among the number of turtles with the variables stream margin, stream section, substrate type, year season, size class and sex. In order to compare with previous works on the species we used five size classes (SC) based on SCL (see Semeñiuk et al. 2019). 
Table 2 Detail of the stream width and water depth (means) of each transect along the three sections

\begin{tabular}{|c|c|c|c|c|c|c|}
\hline \multirow[b]{2}{*}{ Transect } & \multicolumn{2}{|l|}{$\mathrm{S} 1$} & \multicolumn{2}{|l|}{$\mathrm{S} 2$} & \multicolumn{2}{|l|}{ S3 } \\
\hline & Mean Width & Mean Depth & Mean Width & Mean Depth & Mean Width & Mean Depth \\
\hline 1 & 3.57 & 10.33 & 7 & 34.39 & 9.3 & 19.36 \\
\hline 2 & 5.2 & 14.71 & 6.47 & 27.67 & 9.03 & 16.97 \\
\hline 3 & 4.27 & 15.36 & 5.77 & 25.2 & 8.57 & 12.97 \\
\hline 4 & 3.13 & 9.78 & 5.23 & 27.11 & 9.3 & 11.91 \\
\hline 5 & 3.7 & 12 & 6.87 & 29.45 & 8.33 & 12.71 \\
\hline Mean & 3.97 & 12.44 & 6.27 & 28.76 & 8.91 & 14.78 \\
\hline $\mathrm{Sd}$ & 0.80 & 2.52 & 0.75 & 3.49 & 0.44 & 3.22 \\
\hline
\end{tabular}

A factorial analysis of variance (ANOVA) (Zar 1999) was run to evaluate effects of stream sections, stream margins and substrate types (factors) in the number of turtles caught (dependent variable). Transects were the sampling units, and data were fourth-root transformed to approach the assumptions of the test.

The aggregative or not aggregative use of refuges was evaluated taking into account the locations of turtle capture within each transect and margin, and measuring the distance (m) between adjacent individuals. Recaptures were used to assess patterns of recurrence in the use of refuges.
All analyses were performed with the software Statistica 7.0 under a significant $p$ value of 0.05 . Recaptured turtles were not included in the analyses (except to evaluate the recurrence of refuge use) to avoid data pseudoreplication.

\section{Results}

We caught 109 individuals of $H$. tectifera (mean $\pm \mathrm{SD}=$ $15.71 \pm 3.68$ individuals/survey; $n=7$ ): 56 males, 46 females and 7 hatchling turtles for which sex could not be determined.

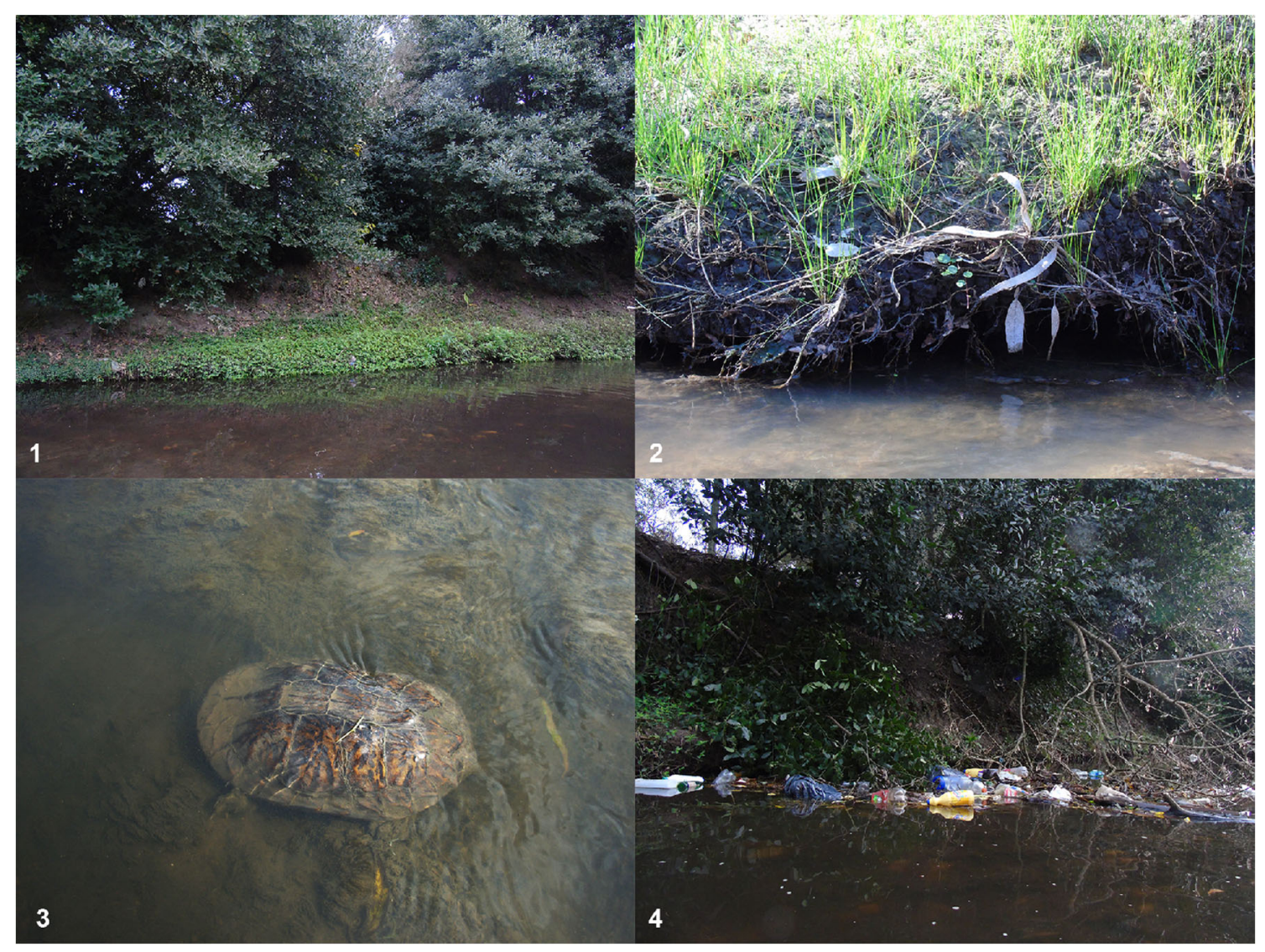

Fig. 1 Substrate types used by turtles as underwater refuges: (1) marginal aquatic vegetation; (2) hollows on the stream margins; (3) nude stream bottom, and (4) other substrate types (garbage accumulations, logs and dams composed by rests of aquatic and terrestrial vegetation that floats freely) 
Table 3 Area occupied $\left(\mathrm{m}^{2}\right)$ by each substrate type in the three studied stream sections of Rodriguez stream

\begin{tabular}{llllll}
\hline Site & Margin & $\begin{array}{l}\text { Marginal aquatic } \\
\text { vegetation }\end{array}$ & $\begin{array}{l}\text { Hollows on } \\
\text { margins }\end{array}$ & $\begin{array}{l}\text { Nude stream } \\
\text { bottom }\end{array}$ & $\begin{array}{l}\text { Other substrate } \\
\text { types }\end{array}$ \\
\hline S3 & $\mathrm{S}$ & 33.68 & 0.21 & 150 & 1.50 \\
& $\mathrm{~N}$ & 9.49 & 1.94 & 150 & 1.70 \\
$\mathrm{~S} 2$ & $\mathrm{~S}$ & 0 & 11.54 & 150 & 0.09 \\
& $\mathrm{~N}$ & 0.24 & 0.31 & 150 & 1.46 \\
$\mathrm{~S} 1$ & $\mathrm{~S}$ & 2.49 & 3.86 & 150 & 0 \\
& $\mathrm{~N}$ & 0.88 & 8.54 & 150 & 0 \\
\hline
\end{tabular}

Most turtles were caught in hollows in the stream banks $(55.05 \%)$, being the remaining ones under marginal aquatic vegetation $(19.27 \%)$, resting still on the nude stream bottom $(17.43 \%)$, and under other substrate types such as garbage accumulations, $\operatorname{logs}$ and floating dams of aquatic and terrestrial vegetation; $(8.26 \%)$.

Table 3 summarizes the area occupied by each substrate type on both margins of the three stream sections. In the least urbanized sites (S1 and S2) hollows prevailed over marginal aquatic vegetation and other substrate types. This fact explains the high use of hollows by turtles in these sections (see below), while site 3 has higher availability of marginal aquatic vegetation. Coincidentally, turtles of this site used this type of refuge more frequently than the other types (see below; Table 4).

The Multiple Correspondence Analyses (MCA) revealed the relationships among the studied variables and the different habitats used by H. tectifera in the Rodriguez stream (Fig. 2). In general, according to the MCA, turtles from the most urbanized site (S3) were predominantly found on the north margin $(71.74 \%)$ and using the four types of substrate. The most used refuge by both sexes on site 3 was the marginal aquatic vegetation (males: $45.83 \%$, females: $41.18 \%$ ), whilst at the other sites the analysis reflected a high use of hollows at S1 (males: $83.33 \%$, females: $85.71 \%$ ), especially on the north margin, and S2 (males: $73.68 \%$, females: $75.00 \%$ ), mainly on the south margin (Table 4, Fig. 2a,b). Percentage of turtles caught on the nude stream bottom was highest at S2 followed by S3 (Table 4). On the other hand, individuals on other substrate types (garbage accumulations, logs and floating rests of aquatic and terrestrial vegetation) were found only in S3, being similar the percentage of males and females $(20.83 \%$ and $23.53 \%$, respectively) (Table 4 , Fig. 2b).

Thus, according this analysis, the refuges used by turtles varied among sites but not between sexes. As well, turtles used several patterns of refuge according to size class and year season. Although all size classes used hollows, the small (SC I) and medium-sized (SC III) turtles were mostly found on nude stream bottom, whereas large turtles (SC IV, 200-250 mm) predominated under marginal aquatic vegetation (Fig. 2c). Throughout the year, marginal hollows were the most used substrate (Table 5), especially in autumn and spring; in winter, in addition to hollows, most turtles were associated with marginal aquatic vegetation; and in summer, with nude stream bottom (Fig. 2d, Table 5). Although turtles were caught in the three sites across all year seasons (Table 6), during autumn turtles predominated at S2, while in winter and summer they appeared mainly in S3, and in spring, they were mostly found in S1 (Fig. 2e).

In sum, the MCA analysis showed that turtles display a different use of refuges according to size class, stream section, stream margin, and year season, but not according to sex (see Discussion).

The ANOVA results were significant for the number of turtles found under different substrate types among stream margins and sections (interaction: $\mathrm{F}_{4,612}=7.48, p<0.0001$ ), and confirmed the relationship reflected by the MCA (Fig. 2a).

Each of the 14 turtles recaptured during this work was found in the same stream section, and many of them were even in the same stream margin and transect (ten cases) indicating a high site fidelity during the one-year period of the study. Regarding the substrate types, turtles from the most urbanized site (S3) were mainly recaptured in a different
Table 4 Percentage (\%) of turtles caught associated to each type of refuge in the three sections of the Rodriguez stream

\begin{tabular}{llllll}
\hline Site & Sex & Hollows on margins & $\begin{array}{l}\text { Nude stream } \\
\text { bottom }\end{array}$ & $\begin{array}{l}\text { Marginal aquatic } \\
\text { vegetation }\end{array}$ & $\begin{array}{l}\text { Other substrate } \\
\text { types }\end{array}$ \\
\hline S3 & F & 17.65 & 17.65 & 41.18 & 23.53 \\
& M & 25.00 & 8.33 & 45.83 & 20.83 \\
S2 & F & 75.00 & 18.75 & 6.25 & 0.00 \\
& M & 73.68 & 26.32 & 0.00 & 0.00 \\
S1 & F & 85.71 & 7.14 & 7.14 & 0.00 \\
& M & 83.33 & 8.33 & 8.33 & 0.00 \\
\hline
\end{tabular}


a) 2 Plot of Column Coordinates; Dimension: $1 \times 2$

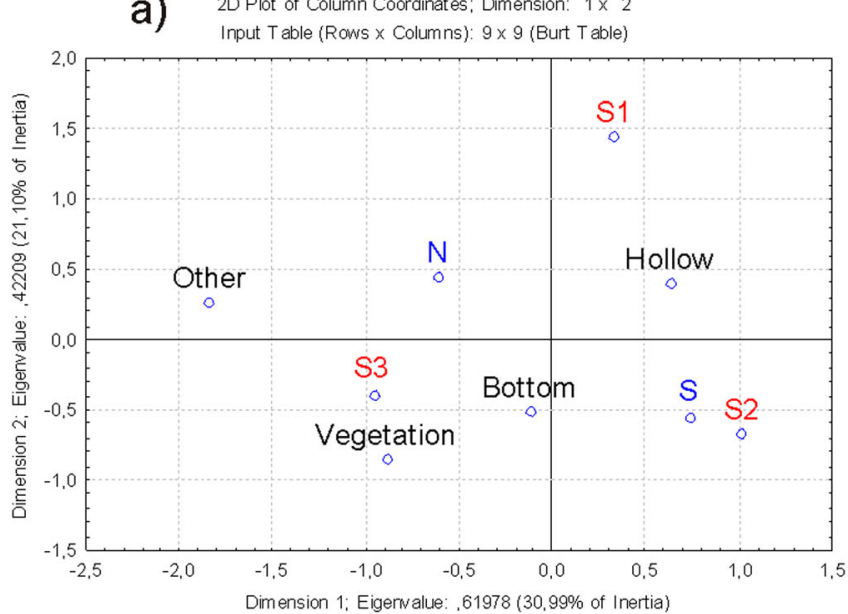

C) 2D Plot of Column Coordinates; Dimension: $1 \times 2$

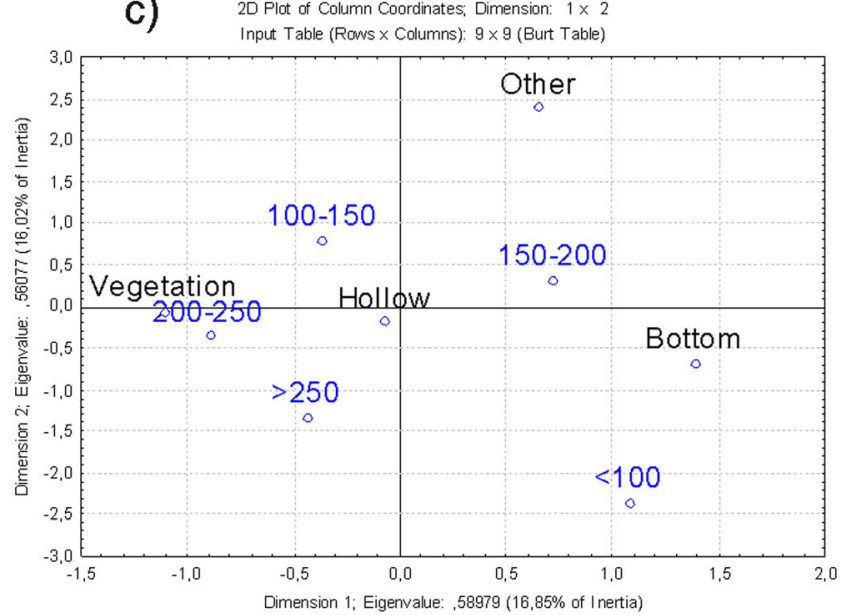

b) $2 \mathrm{D}$ Plot of Column Coordinates; Dimension: $1 \times 2$

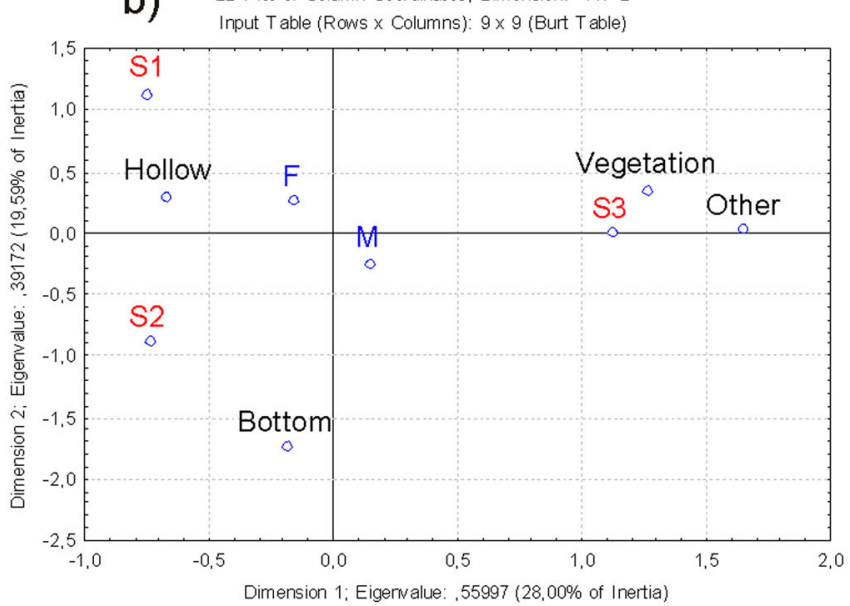

d)

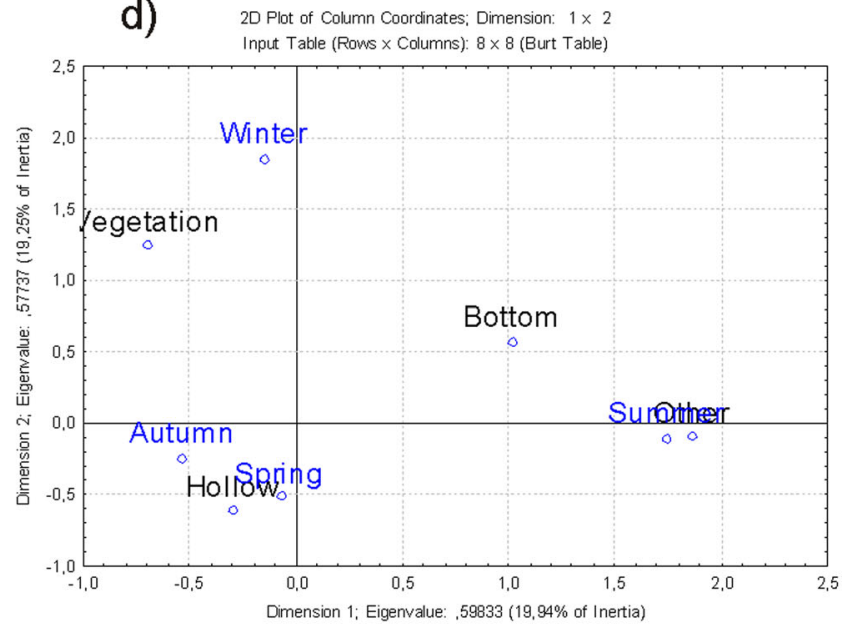

e)

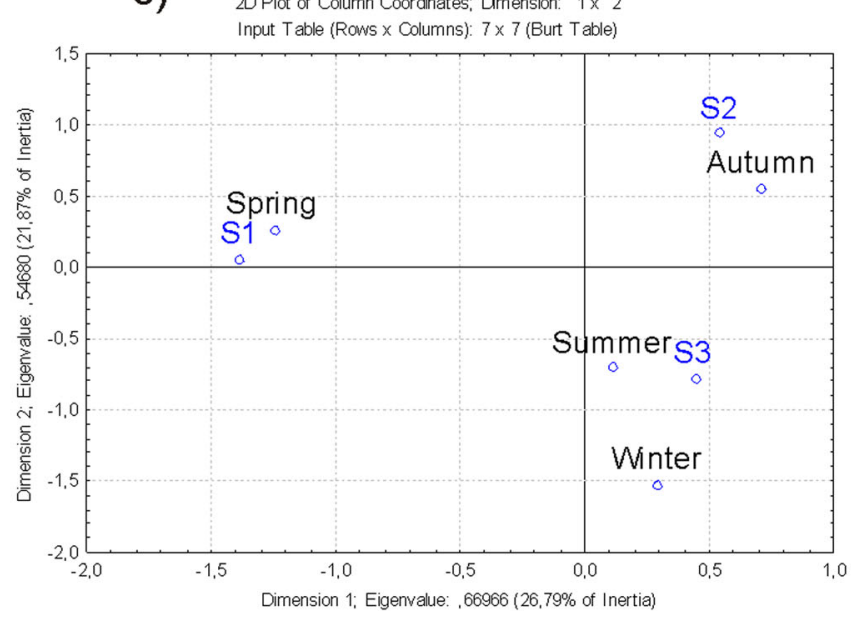

Fig. 2 Multiple correspondence analysis (MCA) plots for (a) substrate type in relation to stream section (Sites 1-3: S1, S2, S3) and stream margin (N: north, $\mathrm{S}$ : south); (b) sex of turtles (male: $\mathrm{M}$, female: $\mathrm{F}$ ) in

substrate type respect to the first capture. Instead, S2 and S1 turtles that were first captured in hollows were always recaptured in hollows on the same margin but never in the same hollow than the first capture. relation to substrate type and stream section; (c) class size in relation to substrate type; (d) substrate type in relation to year season, and (e) year season in relation to stream section

In relation to the aggregative patterns of $H$. tectifera, we obtained a mean distance between consecutive turtles of: 3.50 $\pm 3.46 \mathrm{~m}(\mathrm{~S} 1), 5.35 \pm 7.23 \mathrm{~m}(\mathrm{~S} 2)$, and $4.79 \pm 4.70 \mathrm{~m}(\mathrm{~S} 3)$. We observed an aggregative use of hollows in 11 cases (3 in S3, 7 
Table 5 Percentage (\%) of turtles captured in each type of refuge during the year seasons

\begin{tabular}{lllll}
\hline Year season & $\begin{array}{l}\text { Marginal aquatic } \\
\text { vegetation }\end{array}$ & $\begin{array}{l}\text { Nude stream } \\
\text { bottom }\end{array}$ & $\begin{array}{l}\text { Hollows on } \\
\text { margins }\end{array}$ & $\begin{array}{l}\text { Other substrate } \\
\text { types }\end{array}$ \\
\hline Autumn & 23.26 & 11.63 & 65.12 & 0.00 \\
Winter & 35.71 & 21.43 & 42.86 & 0.00 \\
Spring & 16.13 & 16.13 & 61.29 & 6.45 \\
Summer & 14.29 & 28.57 & 57.14 & 0.00 \\
\hline
\end{tabular}

in S2, 1 in S1), being in some cases up to four turtles together in the same hollow (e.g., in S2).

\section{Discussion}

This is the first study of the habitat requirements of Hydromedusa tectifera in an urban-impacted stream of the suburbs of La Plata city. This study complements a previous paper on abundance and sex-size class structure of the same population (Semeñiuk et al. 2019). Turtles use different types of underwater refuges depending on stream section, stream margin, year season, and size class of individuals, but show no difference between sexes.

Most of the studies about habitat use of freshwater turtles are focused on species from the Northern Hemisphere (Hartwig and Kiviat 2007; Haramura et al. 2011; Millar and Blouin-Demers 2011; Forero-Medina et al. 2012; Refsnider and Linck 2012; Wieten et al. 2012; Hill and Vodopich 2013; Markle and Chow-Fraser 2014; Brown 2016; Pittfield and Burger 2017; Dupuis-Desormeaux et al. 2018). But, only a few researchers have focused on how urbanization impacts the habitat of turtles (Ryan et al. 2008; De Lathouder et al. 2009; Refsnider and Linck 2012; Hill and Vodopich 2013; Ryan et al. 2014; Brown 2016; Elston et al. 2016; Ferronato et al. 2016; Pittfield and Burger 2017).

Ryan et al. (2008) reported that human activities influence freshwater turtle habitat selection. Complex habitat types provide shelter and camouflage from possible disturbances, and increase food resources; some turtles may benefit from nutrients by taking advantage of the high productivity in these areas (Wieten et al. 2012).

In this study, we demonstrate that availability of turtle refuges differs among the three studied sections of the Rodriguez stream and that their use varies in relation to availability. The

Table 6 Percentage (\%) of turtles captured in the three sections of the Rodriguez stream during all year seasons

\begin{tabular}{llll}
\hline Year season & S3 & S2 & S1 \\
\hline Autumn & 41.86 & 44.19 & 13.95 \\
Winter & 50.00 & 28.57 & 21.43 \\
Spring & 29.03 & 22.58 & 48.39 \\
Summer & 35.71 & 35.71 & 28.57 \\
\hline
\end{tabular}

most used refuges considering the three sections as a whole were the hollows on the margins $(55.05 \%)$ and marginal aquatic vegetation (19.27\%), both explaining the $74.32 \%$ of the refuges occupied by turtles. Thus, it is esential to keep the stream margins unaltered as a conservation policy in order to favor the presence of turtles in urban environments. Margins of the studied stream, mainly in the most urbanized site (S3), are periodically altered by channelization works (held every 4-5 years) and vegetation clearing (monthly or bimonthly) tending to improve water drainage without considering the preservation of the fauna that inhabits the stream. Channelization works are carried out with heavy backhoe shovels that enter the stream causing a high impact not only by alteration of the habitat characteristics but also by direct damage to many species, as we personally verified how some turtles were crushed during works (see reports of similar damage in Plummer and Mills 2008).

Systematic weeding works made on marginal aquatic vegetation do not appear to be as invasive as channelization but introduce a periodic stressing factor that also reduces microhabitat availability. Turtles choose certain streams over others based on vegetation cover, since riparian vegetation modulates water temperature, improves water quality, provides refuge, and increases food availability (Cortelezzi et al., 2013; ForeroMedina et al., 2012), being the last two factors important habitat requirements for turtle populations (Ercolano, 2008).

In soft bottom streams, turtles are capable to bury themselves in the mud to avoid predators, in addition to the use of hollows, as reported by Famelli et al. (2016) for H. maximiliani; but the bottom of the Rodriguez stream is predominantly rough and with scarce soft areas where turtles could dig into. In fact, only a few turtles from the Rodriguez stream $(17.43 \%)$ seem to choose the nude stream bottom to stay still and camouflage instead of taking refuge within hollows or under floating or rooted vegetation. The strategy of staying still and camouflaging on the nude bottom but without digging into was reported for the population of $H$. tectifera from the mountain streams of Córdoba province. The bottom of these streams is rich in fixed and free stones among which turtles can better camouflage themselves (Molina and Leynaud 2017). The frequency of use of nude bottom by the studied population of $H$. tectifera was low in the stream section characterized by low water depth (S1 with $7.14 \%$ ) and increased in the deeper sections (S2 and S3 with $22.86 \%$ and 
$19.57 \%$ respectively). The greater depth in S2 and S3 sections is in part explained by water discharges constantly produced by the surrounding urbanization. The deepest section (S2) is located downstream of a closed neighborhood and occasionally receives water discharges, and $\mathrm{S} 3$ receives lots of pluvial drainages from the surrounding houses and streets. It seems evident that higher urbanization levels cause higher water levels in the middle and lower sections of the Rodriguez stream, providing additional refuge for the turtles during seasonal fluctuations and influencing the dynamics of microhabitat use. Thus, destruction of microhabitats on the stream margins (vegetation and hollows) should surely have a greater impact in the $\mathrm{S} 1$ section, since low water depth tends to avoid the use of nude bottom as refuge.

In addition, our data show that turtles of all class sizes and of both sexes refuge into hollows on the stream margins. Although different microhabitats provide refuge for turtles during all year seasons, hollows are the most important refuge during extreme cold and extreme hot seasons. Similarly, Famelli et al. (2016) reported that the sister species Hydromedusa maximiliani displays intense use of burrows throughout the year.

Turtle recaptures evidence a recurrence and aggregative pattern in the use of refuges. This recurrence would be related, at least in 1-year period, to a high spatial fidelity of individuals of the studied population, since all recaptures have occurred in the same stream section as the first capture and most of them even in the same transect. Substrate availability modulates the recurrence in the use of refuges; our results also revealed that turtles from stream sites with high availability of refuge types (S3) were recaptured on a different substrate type than the first capture. Conversely, at S1 and S2 sites (lower availability of refuge types) individuals were always recaptured in hollows. A similar spatial fidelity was reported for $H$. maximiliani, a species that uses a small area of aquatic habitat to feed and refuge (Famelli et al. 2016).

The aggregation of two or more turtles into the same hollow is another characteristic of the microhabitat use of $H$. tectifera. This phenomenon was observed along the entire stream but was marked at site S2 which can be explained by the large number of hollows at this site.

Many authors have foccused attention on the worldwide decrease of several populations of freshwater turtles (Browne and Hecnar 2007; Enneson and Litzgus 2009; Lovich et al. 2018; Howell et al. 2019; Van Dyke et al. 2019). The factors causing such a decline seem to be habitat destruction and fragmentation as the most important for several species, but harvesting and pollution have also impact on others (Lovich et al., 2018; Van Dyke et al. 2019). With respect to habitat loss, important areas of the geographic distribution of certain species coincide almost totally with human settlements as is the case of Hydromedusa tectifera. Thus, urban development and the different ways of habitat modification that cities imply are one of the most crucial factors for the survival of the species in certain areas. Although it is currently recognized as not threatened for Argentina (Prado et al. 2012) and Uruguay (Carreira et al. 2007), as well as "Least Concern" for Brazil (Vogt et al. 2015) and also internationally (Rhodin et al. 2017, 2018), the southernmost core populations of $H$. tectifera coincide almost totally with the second largest human settlement in South America: the Area Metropolitana y Conurbano Bonaerense (AMBA, Argentina), where more than 10 million people live (INDEC 2016; Sánchez et al. 2019). In this context, the generation of knowledge and implementation of basin management policies for the streams of the area are crucial to avoid a severe decline and even local extinction of $H$. tectifera.

Finally, some general conclusions may be drawn: (1) Hydromedusa tectifera uses a diversity of underwater refuges; (2) the use of the different refuges varies according to the refuge availability in relation to the characteristics of the stream and to the urban impacts along the stream sections; (3) hollows on the stream margins are a key refuge for $H$. tectifera since they are the most used refuge by turtles of both sexes and all class sizes throughout the stream during all year seasons; (4) patterns of recurrence depend on the availability of substrate type; (5) aggregative use of refuges (hollows) occurs in response to a lower offer of this type of refuge. This information provides insight into key aspects of the microhabitat requirements of Hydromedusa tectifera that should be useful in mitigating and preventing the negative effects of the current stream management policies carried out by municipal authorities with no regard for effects on biodiversity of streams, particularly turtles.

Acknowledgments This paper is Scientific Contribution $\mathrm{N}^{\circ} 1169$ of the Institute of Limnology "Dr. Raúl A. Ringuelet" (ILPLA, CONICET, UNLP). The authors acknowledge Consejo Nacional de Investigaciones Científicas y Técnicas (CONICET) and Universidad Nacional de La Plata (UNLP) for continuous support. We thank to Ministerio de Asuntos Agrarios from Buenos Aires province (MAABA) for permits $\left(N^{\circ} 102 /\right.$ 2014-1025 and 69/2016).

\section{References}

Bowne DR, Cosentino BJ, Anderson LJ, Bloch CP, Cooke S, Crumrine PW, Dallas J, Doran A, Dosch JJ, Druckenbrod DL, Durtsche RD, Garneau D, Genet KS, Fredericksen TS, Kish PA, Kolozsvary MB, Kuserk FT, Lindquist ES, Mankiewicz C, March JG, Muir TJ, Murray KG, Santulli MN, Sicignano FJ, Smallwood PD, Urban RA, Winnett-Murray K, Zimmermann CR (2018) Effects of urbanization on the population structure of freshwater turtles across the United States. Conserv Biol 32:1150-1161. https://doi.org/10.1111/ cobi.13136

Brown B (2016) Freshwater turtle population characteristics and habitat use within Ontario's Dunnville marsh area. Dissertation, University of Waterloo 
Browne CL, Hecnar SJ (2007) Species loss and shifting population structure of freshwater turtles despite habitat protection. Biol Conserv 138:421-429. https://doi.org/10.1016/j.biocon.2007.05.008

Cabrera MR (1998) Las tortugas continentales de Sudamérica austral. Mario Cabrera, Córdoba

Cagle FR (1939) A system of marking turtles for future identification. Copeia 1939:170-173

Carreira S, Estrades A, Achaval F (2007) Estado de conservación de la fauna de tortugas (Reptilia, Testudines) de Uruguay. Bol Soc Zool $16: 20-25$

Cortelezzi A, Sierra M, Gómez N, Marinelli C, Rodrígues Capítulo A (2013) Macrophytes, epipelic biofilm, and invertebrates as biotic indicators of physical habitat degradation of lowland streams (Argentina). Environ Monit Assess 185:5801-5815. https://doi. org/10.1007/s10661-012-2985-2

De Lathouder R, Jones DN, Balcombe SR (2009) Assessing the abundance of freshwater turtles in an Australian urban landscape. Urban Ecosyst 12:215-231. https://doi.org/10.1007/s11252-008-0077-4

Dupuis-Desormeaux M, Davy C, Lathrop A, Followes E, Ramesbottom A, Chreston A, MacDonald SE (2018) Colonization and usage of an artificial urban wetland complex by freshwater turtles. PeerJ 6: e5423. https://doi.org/10.7717/peerj.5423

Elston JE, Rolland V, Trauth SE (2016) Urban ditch characteristics associated with turtle abundance and species richness. Herpetol Conserv Biol 11(1):132-141

Enneson JJ, Litzgus JD (2009) Stochastic and spatially explicit population viability analyses for an endangered freshwater turtle, Clemmys guttata. Can J Zool 87:1241-1254. https://doi.org/10.1139/Z09-112

Ercolano E (2008) Aquatic and terrestrial habitat use of the Australian freshwater turtle, Chelodina expansa. Dissertation, Bucknell University

Eskew EA, Price SJ, Dorcas ME (2010a) Survival and recruitment of semi-aquatic turtles in an urbanized region. Urban Ecosyst 13: 365-374. https://doi.org/10.1007/s11252-010-0125-8

Eskew EA, Price SJ, Dorcas ME (2010b) Survivorship and population densities of painted turtles (Chrysemys picta) in recently modified suburban landscapes. Chelonian Conserv Bi 9:244-249. https://doi. org/10.2744/CCB-0823.1

Famelli S, Souza FL, Georges A, Bertoluci J (2016) Movement patterns and activity of the Brazilian snake-necked turtle Hydromedusa maximiliani (Testudines: Chelidae) in southeastern Brazil. Amphibia-Reptilia 37:215-228. https://doi.org/10.1163/1568538100003047

Ferronato BO, Roe JH, Georges A (2016) Urban hazards: spatial ecology and survivorship of a turtle in an expanding suburban environment. Urban Ecosyst 19:415-428. https://doi.org/10.1007/s11252-0150506-0

Ferronato BO, Roe JH, Georges A (2017) Responses of an Australian freshwater turtle to drought-flood cycles along a natural to urban gradient. Austral Ecol 42:442-455. https://doi.org/10.1111/aec. 12462

Forero-Medina G, Cárdenas-Arévalo G, Castaño-Mora OV (2012) Habitat modeling of Dahl's toad-headed turtle (Mesoclemmys Dahli) in Colombia. Herpetol Conserv Bio 7:313-322

French SS, Webb AC, Hudson SB, Virgin EE (2018) Town and country reptiles: a review of reptilian responses to urbanization. Integr Comp Biol 58:948-966. https://doi.org/10.1093/icb/icy052

Hamer AJ, Harrison LJ, Stokeld D (2018) Terrestrial habitat and individual fitness increase survival of a freshwater turtle in an urban landscape. Urban Ecosyst 21:71-83. https://doi.org/10.1007/s11252017-0708-8

Haramura T, Yamane M, Mori A (2011) Radiotelemetric study of movement patterns of lotic freshwater turtles during breeding and hibernation seasons. J Freshw Ecol 25:251-259. https://doi.org/10.1080/ 02705060.2010 .9665075
Hartwig TS, Kiviat E (2007) Microhabitat association of Blanding's turtles in natural and constructed wetlands in southeastern New York. J Wildlife Manage 71:576-582. https://doi.org/10.2193/2005-619

Hill SK, Vodopich DS (2013) Habitat use and basking behavior of a freshwater turtle community along an urban gradient. Chelonian Conserv Bi 12:275-282. https://doi.org/10.2744/CCB-0961.1

Howell HJ, Legere RH, Holland DS, Seigel RA (2019) Long-term turtle declines: protected is a verb, not an outcome. Copeia 107:493-501. https://doi.org/10.1643/CH-19-177

INDEC 2016. http://www.indec.gov.ar/

Lovich JE, Ennen JR, Agha M, Gibbons JW (2018) Where have all the turtles gone, and why does it matter? BioScience 68:771-781. https://doi.org/10.1093/biosci/biy095

Marchand MN, Litvaitis JA (2004) Effects of landscape composition, habitat features, and nest distribution on predation rates of simulated turtle nests. Biol Conserv 117 (3):243-251

Markle CE, Chow-Fraser P (2014) Habitat selection by the Blanding's turtle (Emydoidea blandingii) on a protected island in Georgian bay, Lake Huron. Chelonian Conserv Bi 13:216-226. https://doi.org/10. 2744/CCB-1075.1

Millar CS, Blouin-Demer G (2011) Spatial ecology and seasonal activity of blanding's turtles (Emydoidea blandingii) in Ontario, Canadá. J Herpetol 45:370-378. https://doi.org/10.1670/10-172.1

Mitchell JC, Brown REJ, Bartholomew B (2008) Urban herpetology. Society for the Study of Amphibians and Reptiles, Salt Lake City

Molina FJ, Leynaud GC (2017) Thermoconformity strategy in the freshwater turtle Hydromedusa tectifera (Testudines, Chelidae) in its southern distribution area. J Therm Biol 69:178-183. https://doi. org/10.1016/j.jtherbio.2017.07.008

Ner SE, Burke RL (2008) Direct and indirect effects of urbanization on diamond-backed terrapins of the Hudson River bight: distribution and predation in a human-modified estuary. In: Mitchell JC, Brown J, Bartholomew B (eds) Urban herpetology. Society for the Study of Amphibians and Reptiles, Salt Lake City, pp 107-117

Pittfield T, Burger J (2017) Basking habitat use and response of freshwater turtles to human presence in an urban canal of Central New Jersey. Urban Ecosyst 20:449-461. https://doi.org/10.1007/ s11252-016-0606-5

Plummer MV, Mills NE (2008) Structure of an urban population of softshell turtles (Apalone spinifera) before and after stream alteration. In: Mitchell JC, Brown REJ, Bartholomew B (eds) Urban herpetology. Salt Lake City, UT, Society for the Study of Amphibians and Reptiles, pp 95-105

Prado WS, Waller T, Albareda DA, Cabrera MR, Etchepare E, Giraudo AR, González Carman V, Prosdocimi L, Richard E (2012) Categorización del estado de conservación de las tortugas de la República Argentina. Cuad Herpetol 26:375-388

Rees M, Roe JH, Georges A (2009) Life in the suburbs: behavior and survival of a freshwater turtle in response to drought and urbanization. Biol Conserv 142:3172-3181. https://doi.org/10.1016/j. biocon.2009.08.019

Refsnider JM, Linck MH (2012) Habitat use and movement patterns of blanding's turtles (Emydoidea blandingii) in Minnesota, USA: a landscape approach to species conservation. Herpetol Conserv Bio 7:185-195

Rhodin AGJ, Iverson JB, Bour R, Fritz U, Georges A, Shaffer HB, van Dijk PP (2017) Turtles of the world: Annotated checklist and atlas of taxonomy, synonymy, distribution, and conservation status. In: Rhodin AGJ, Iverson JB, van Dijk PP, Saumure RA, Buhlmann KA, Pritchard PCH, Mittermeier RA (eds) Conservation Biology of Freshwater Turtles and Tortoises: A Compilation Project of the IUCN/SSC Tortoise and Freshwater Turtle Specialist Group, Chelonian Research Monographs, 8th edn. Chelonian Research Foundation, New York. pp 1-292

Rhodin AGJ, Stanford CB, Van Dijk PP, Eisemberg C, Luiselli L, Van Dijk PP et al (2018) Global conservation status of turtles and 
tortoises (order Testudines). Chelonian Conserv Bi 17:135-161. https://doi.org/10.2744/CCB-1348.1

Roe JH, Rees M, Georges A (2011) Suburbs: dangers or drought refugia for freshwater turtle populations? J Wildlife Manage 75:1544-1552

Rodrigues JFM, Oliveira Soares D, Silva JRF (2014) Sexing freshwater turtles: penile eversion in Phrynops tuberosus (Testudines: Chelidae). Acta Herpetol 9:259-263

Ryan TJ, Conner CA, Douthitt BA, Sterrett SC, Salsbury CM (2008) Movement and habitat use of two aquatic turtles (Graptemys geographica and Trachemys scripta) in an urban landscape. Urban Ecosyst 11:213-225. https://doi.org/10.1007/s11252-008-0049-8

Ryan TJ, Peterman WE, Stephens JD, Sterrett SC (2014) Movement and habitat use of the snapping turtle in an urban landscape. Urban Ecosyst 17:613-623. https://doi.org/10.1007/s11252-013-0324-1

Sánchez RM, Semeñiuk MB, Cassano MJ, Alcalde L, Leynaud GC, Moreno L (2019) Review of chelid and emydid turtle distributions in southern South America with emphasis on extralimital populations and new records for Argentina. Herpetol J 29:219-229. https:// doi.org/10.33256/hj29.4.219229

Santoro A (2017) The impact of urbanisation on the south-western snakenecked turtle (Chelodina colliei). Murdoch University, Dissertation

Semeñiuk MB, Sánchez RM, Cassano MJ, Palumbo E, Alcalde L (2019) Abundance and population structure of Hydromedusa tectifera cope 1869 in a highly anthropogenic environment in Argentina. Chelonian Conserv Bi 18:24-31. https://doi.org/10.2744/CCB1318.1
Sterrett SC, Smith LL, Golladay SW, Schweitzer SH, Maerz JC (2011) The conservation implications of riparian land use on river turtles. Animal Cons 14:38-46

Stokeld D, Hamer AJ, Van Der Ree R, Pettigrove V, Gillespie G (2014) Factors influencing occurrence of a freshwater turtle in an urban landscape: a resilient species? Wildlife Res 41:163-171

Vanek JP, Glowacki GA (2019) Assessing the impacts of urbanization on sex ratios of painted turtles (Chrysemys picta). Diversity. 11. https:// doi.org/10.3390/d11050072

Van Dyke JU, Spencer R-J, Thompson MB, Chessman B, Howard K, Georges A (2019) Conservation implications of turtle declines in Australia's Murray River system. Sci Rep 9:1-12. https://doi.org/ 10.1038/s41598-019-39096-3

Vogt RC, Fagundes CK, Bataus YSL, Balestra RAM, Batista FRW, Uhlig VM, Silveira AL, Bager A, Batistella AM, Souza FL, Drummond GM, Reis IJ, Bernhard R, Mendonça SHST, Luz VLF (2015) Avaliação do Risco de extinção de Hydromedusa tectifera cope, 1869 no Brasil. Processo de avaliação do risco de extinção da fauna brasileira.ICMBio.http://www.icmbio.gov.br/portal/biodiversidade/ fauna-brasileira/estado-de-conservacao/7402-repteis-hydromedusatectifera-cagado-de-pescoco-de-cobra.html

Wieten AC, Cooper MJ, Parker AD, Uzarski DG (2012) Great Lakes coastal wetland habitat use by seven turtle species: influences of wetland type, vegetation, and abiotic conditions. Wetl Ecol Manag 20:47-58. https://doi.org/10.1007/s11273-011-9240-4

Zar JH (1999) Biostatistical analysis. Prentice Hall, Upper Saddle River 